\title{
PENGARUH PENDIDIKAN GIZI DENGAN MENGGUNAKAN MEDIA KOMIK TERHADAP PENGETAHUAN GIZI SEIMBANG ANAK KELAS 5 SEKOLAH DASAR DI SDN CIRIUNG 02 CIBINONG TAHUN 2017
}

\author{
The Effect Of Nutritional Education Using Comic Media On Nutrition \\ Knowledge Between Basic School 5 Class Children In Ciriung 02 SDN \\ Cibinong 2017
}

\author{
Nadya Anggraeni ${ }^{1}$ Sintha Fransiske $S^{2}$ \\ ${ }^{1}$ FIKES Universitas Pembangunan Nasional "Veteran” Jakarta \\ sintha_fs@yahoo.com
}

\begin{abstract}
Guidelines for balanced nutrition began to be introduced and socialized more than 15 years ago. Guidelines for balanced nutrition apply to every stage of age including school-aged children. Education of balanced nutrition is still little given to school-aged children. According to some research is still a lot of prevalence of knowledge of balanced nutrition is lacking. In the study conducted Zulaekah (2012) showed that as many as $57.7 \%$ of primary school children have a lack of nutrition knowledge. This study aims to determine whether there is influence of nutrition education by using Comic media on knowledge of balanced nutrition. In this research use quasy experimental research design with time series design design. This research is done by using comic print media which contains about 4 messages of balanced nutrition, that is variation of food, the importance of clean life, the importance of active lifestyle and exercise, and the importance of monitoring the weight which is visualized in a tumpeng gizi seimbang (TGS). Statistical analysis of data using $t$-dependent test. The result of $t$-dependent test shows that there is an increase of average value of knowledge before and after giving comic 36,36. In this research, balanced comic nutrition media can increase the average knowledge of schoolchild by 34,36 or $72,15 \%$.
\end{abstract}

Keywords: Nutrition Education, Nutrition Knowledge

\begin{abstract}
ABSTRAK
Pedoman gizi seimbang mulai diperkenalkan dan disosialisasikan lebih dari 15 tahun yang lalu. Pedoman gizi seimbang berlaku untuk setiap tahap usia termasuk anak usia sekolah. Pendidikan gizi seimbang masih sedikit diberikan kepada anak usia sekolah. Menurut beberapa penelitian masih banyak prevalensi pengetahuan gizi seimbang yang kurang. Dalam penelitian yang dilakukan Zulaekah (2012) menunjukkan bahwa sebanyak $57,7 \%$ anak sekolah dasar memiliki pengetahuan gizi yang kurang. Penelitian ini bertujuan untuk mengetahui ada tidaknya pengaruh pendidikan gizi dengan menggunakan media komik terhadap pengetahuan gizi seimbang. Dalam penelitian ini menggunakan desain penelitian eksperimental quasy dengan desain seri waktu. Penelitian ini dilakukan dengan menggunakan media cetak komik yang berisi sekitar 4 pesan nutrisi seimbang, yaitu variasi makanan, pentingnya hidup bersih, pentingnya gaya hidup aktif dan olahraga, dan pentingnya pemantauan berat badan yang divisualisasikan dalam suatu tumpeng gizi seimbang (TGS). Analisis statistik data menggunakan uji t-dependen. Hasil uji t-dependen menunjukkan bahwa ada peningkatan nilai rata-rata pengetahuan sebelum dan sesudah pemberian komik 36,36. Dalam penelitian ini, media nutrisi komik seimbang dapat meningkatkan rata-rata pengetahuan anak sekolah sebesar 34,36 atau 72,15\%.
\end{abstract}

Kata Kunci : Pendidikan Gizi, Pengetahuan Gizi 
J.Gipas, November 2018, Volume 2 Nomor2 ISSN 2599-0152 eISSN 2599-2465 http://jos.unsoed.ac.id/index.php/jgps

\section{PENDAHULUAN}

Salah satu ciri bangsa maju yaitu bangsa yang memiliki tingkat kesehatan, kecerdasan, dan produktivitas kerja yang tinggi. ketiga hal ini dipengaruhi oleh gizi (Kemenkes RI, 2014). Pola hidup sehat, termasuk didalamnya Pola makan dengan Gizi Seimbang merupakan salah satu faktor utama pada kompleksnya permasalahan gizi di indonesia. Anak usia sekolah merupakan jenjang pertumbuhan yang cukup pesat, juga rentan sekali terkena penyakit. Oleh karena itu, masyarakat perlu mendapatkan informasi yang jelas dan memadai tentang pola makan dengan gizi seimbang, termasuk olahraga sebagai komponen pola hidup seimbang (Mulyani, dkk 2014). Dampak dari kurangnya pengetahuan gizi seimbang membuat kebiasaan makan yang salah pada anak sekolah dasar dan dapat mengakibatkan masalah gizi yang serius, seperti obesitas bagi mereka yang kelebihan kalori atau gizi kurang dan stunting bagi mereka yang kekurangan gizi (Nuryanto, 2014).

Rendahnya pengetahuan anak tentang gizi seimbang dapat dilihat berdasarkan pada penelitian yang telah dilakukan sebelumnya. Penelitian yang dilakukan oleh Zulaekah (2012) menunjukkan bahwa sebanyak $57,7 \%$ anak sekolah dasar mempunyai pengetahuan gizi yang kurang dengan nilai rata-rata awal $54,11 \pm 17,74$. Hal serupa ditunjukkan oleh penelitian yang dilakukan oleh Khamida menunjukkan bahwa pengetahuan siswa tidak baik sebanyak 55\% pada kelompok ceramah dengan rata-rata pengetahuan awal 16,4. Hal tersebut menunjukkan bahwa pengetahuan anak sekolah mengenai gizi seimbang masih tergolong rendah.

Komik mampu memberikan hiburan sekaligus pendidikan kepada anak. Menurut Mc Cloud (1993) dan Santyasa (2007) dalam Nugraha (2012) komik mampu menampilkan cerita sederhana dan tulisan dalam bahasa sehari-hari sehingga mudah dipahami dan diminati oleh berbagai kalangan baik anak-anak maupun dewasa. Berbagai penelitian menunjukkan bahwa komik mampu menyampaikan pesan dengan cara yang enarik sehingga mudah dimengerti dan dapat meningkatkan pengetahuan anak. Komik adalah suatu bentuk kartun yang mengungkapkan karakter dan suatu cerita dalam urutan yang dihubungkan dengan gambar. komik dapat memperkaya kecerdasan visual dan bisa mendorong anak untuk menambah pengetahuan 
J.Gipas, November 2018, Volume 2 Nomor2 ISSN 2599-0152 eISSN 2599-2465 http://jos.unsoed.ac.id/index.php/jgps

dengan cerita yang dipaparkan dalam komik (Hamida dkk, 2012).

Hasil studi pendahuluan di SDN Criung 02 Cibinong dengan melakukan wawancara terhadap sepuluh anak sekolah dasar secara random kelas 5 (Lima). Tujuh dari sepuluh tidak mengetahui Pedoman Gizi Seimbang, tiga diantaranya masih mengetahui 4 sehat lima sempurna. Empat diantaranya mengetahui empat sehat lima sempurna tetapi tidak terlalu memahami dari empat sehat lima sempurna. sedangkan tiga lainnya tidak mengetahui apa itu Pedoman Gizi Seimbang. SDN Ciriung 02, menjadi pilihan tempat melakukan penelitian dengan alasan pengetahuan akan Pedoman Gizi Seimbang masih sangatlah kurang. Hal ini dipandang perlu dilakukan penelitian khususnya pengetahuan tentang gizi seimbang.

Berdasarkan uraian diatas maka penelitian ini dilakukan guna mencegah terjadinya kekhawatiran atau kecemasan meskipun belum disadari sepenuhnya oleh anak sekolah dasar. Oleh karena itu peneliti ingin mengetahui "Bagaimanakah Pengaruh Pendidikan Gizi Dengan Menggunakan Media Komik Terhadap Pengetahuan Gizi Seimbang Anak Kelas 5 Sekolah Dasar"

\section{METODE}

Rancangan

penelitian eksperimental ialah penelitian yang dikembangkan untuk mempelajari fenomena dalam kerangka korelasi sebab akibat. Korelasi sebab-akibat ini dipelajari dengan memberikan perlakuan atau manipulasi pada subjek penelitian, untuk kemudian dipelajari efek perlakuan tersebut (Pratiknya, 2008)

Pada penelitian ini digunakan desain penelitian quasy experimental dengan rancangan time series design yaitu seperti rancagan pretest post, kecuali mempunyai keuntungan dengan melakukan observasi sebelum dan sesudah perlakuan (Wibowo, 2014)

Pre-test dan post-test dilakukan untuk mengetahui ada atau tidaknya perubahan tingkat pengetahuan pada kelompok peserta yang diintervensi. Pretest dilakukan sebelum intervensi, sedangkan post-test dilakukan setelah intervensi. Post-test merupakan gambaran sebagai efek dari paparan selama intervensi.

Pengambilan sampel dalam penelitian ini dilakukan dengan meggunakan metode sample random atau sample acak. Dasar dari metode pengambilan acak sederhana adalah untuk memberikan kesempatan yang sama 
kepada unit sampel untuk terpilih sebagai sampel. (Ariawan, 1998). Dalam penelitian ini respondennya adalah anak kelas 5 yang bersekolah di SDN Ciriung 02 Cibinong, Kabupaten Bogor.

\section{HASIL DAN PEMBAHASAN Analisis Univariat}

Usia

Usia responden di SDN Ciriung 02

rata-rata berkisar 10-12 tahun. Data distribusi karakteristik responden berdasarkan usia dapat dilihat pada tabel 3 dibawah ini.

Berdasarkan Tabel 1 usia responden pada penelitian ini adalah 1012 tahun. Anak dengan usia 10 tahun sejumlah 4 orang $(9,8 \%)$, anak dengan usia 11 tahun sejumlah 25 orang $(61,0 \%)$, dan anak dengan usia 12 tahun sejumlah 12 orang $(29,3 \%)$.

Tabel 1 Karakteristik responden berdasarkan usia

\begin{tabular}{c|c|c}
\hline Usia (Tahun) & Frekuensi (n) & Presentase (\%) \\
\hline 10 Tahun & 4 & 9,8 \\
11 Tahun & 25 & 61,0 \\
12 Tahun & 12 & 29,2 \\
\hline Jumlah & $\mathbf{4 1}$ & $\mathbf{1 0 0}$ \\
\hline Rata-rata \pm SD & $\mathbf{1 1 , 2 0} \pm \mathbf{0 , 6}$ & $\mathbf{1 1 , 2 0} \pm \mathbf{0 , 6}$ \\
\hline
\end{tabular}

\section{Jenis Kelamin}

Tabel 2 Distribusi Karakteristik Responden Berdasarkan Jenis Kelamin

\begin{tabular}{rcc}
\hline Jenis Kelamin & Frekuensi (n) & Presentase (\%) \\
\hline Laki-laki & 22 & 53,7 \\
Perempuan & 19 & 46,3 \\
\hline Jumlah & $\mathbf{4 1}$ & $\mathbf{1 0 0}$
\end{tabular}

Pada penelitian ini didapatkan sejumlah 41 responden dari kelas 5A dan 5B. Secara keseluruhan, jumlah jenis kelamin laki laki adalah 22 siswa atau $53,7 \%$ dari total responden yang dibutuhkan. Sementara jumlah siswa perempuan adalah sebanyak
19 siswa atau 46,3\% dari total keseluruhan. Hal ini menunjukkan bahwa proporsi jumlah siswa laki-laki lebih besar dibandingkan dengan proporsi jumlah siswa perempuan. 


\section{Pendidikan Orang Tua}

Tabel 3 Pendidikan Orang Tua

\begin{tabular}{rcccc}
\hline Pendidikan Orang Tua & \multicolumn{2}{c}{ Ayah } & \multicolumn{2}{c}{ Ibu } \\
\cline { 2 - 5 } & $\mathbf{n}$ & $\mathbf{\%}$ & $\mathbf{n}$ & $\mathbf{\%}$ \\
>SMA/Sederajat & 35 & 85,4 & 30 & 73,2 \\
<SMA/Sederajat & 6 & 14,6 & 11 & 26,8 \\
\hline Jumlah & $\mathbf{4 1}$ & $\mathbf{1 0 0}$ & $\mathbf{4 1}$ & $\mathbf{1 0 0}$ \\
\hline
\end{tabular}

Pada tabel 3, terlihat bahwa Sedangkan sebanyak 30 orang $(73,2 \%)$ hampir seluruhnya sebanyak 35 orang $(85,4 \%) \quad$ pendidikan ayah pendidikan ibu adalah >SMA/Sederajat >SMA/Sederajat dan 6 orang $(14,6 \%)$ dan sebanyak 11 orang $(26,8 \%)$ memiliki memiliki pendidikan <SMA/Sederajat.

\section{Pengetahuan Anak Sekolah Mengenai}

\section{Pedoman Gizi Seimbang}

Tabel 4 Distribusi Pengetahuan Anak Sekolah Mengenai Pedoman Gizi Seimbang

\begin{tabular}{cccc}
\hline Variabel & Mean & SD & Min-Max \\
\hline Pre-Test & 50,3 & 9,1 & $35-65$ \\
Post-Test & 85,9 & 3,3 & $80-90$ \\
\hline
\end{tabular}

Berdasarkan hasil analisa pada Tabel 4 terlihat bahwa nilai rata rata pengetahuan anak sekolah sebelum dilakukan intervensi adalah 50,3 dengan standar deviasi 9,1 Nilai terendah 35 dan nilai tertinggi sebesar 65. Sedangkan untuk nilai rata-rata pengetahuan amak sekolah setelah dilakukan intervensi adalah 85,9 dengan standar deviasi 3,3, dan untuk nilai terendah didapatkan sebesar 80 dan nilai tertinggi didapatkan angka 90. Terdapat perbedaan yang sangat signifikan untuk distribusi pengetahuan anak sekolah mengenai pedoman gizi seimbang sebesar $(p=0.000 ; p<0.005)$. 


\section{Analisis Bivariat}

\section{Perbedaan Pengetahuan Gizi Seimbang Anak Sekolah sebelum dan Sesudah Perlakuan}

Perbedaan Pengetahuan Gizi Seimbang Sebelum dan Sesudah Pemberian Komik

\begin{tabular}{rlll}
\hline Variabel & Mean & SD & Sig. \\
\hline Pengetahuan & & & \\
Pre Test & 50.37 & 9.1 & .000 \\
Post Test & 86.71 & 2.4 &
\end{tabular}

Rata-rata nilai pengetahuan sebelum pemberian komik (Pre-Test) adalah 50,37 dengan standar deviasi 9,1. Pada pengetahuan setelah intervensi (Post-Test) didapatkan nilai rata-rata 86,7 dengan standar deviasi 2,4. Terlihat selisih nilai mean antara pengukuran pertama dan kedua adalah $36,34(72,15 \%)$ dengan standar deviasi 8,2. Hasil uji statistic didapatkan nilai $\mathrm{P}$ value 0.000 maka dapat disimpulkan terdapat perbedaan yang signifikan antara pengetahuan sebelum dan sesudah intervensi.

Rata-rata nilai pengetahuan sebelum pemberian komik (Pre-Test) adalah 50,37 dengan standar deviasi 9,1. Pada pengetahuan setelah intervensi (Post-Test) didapatkan nilai rata-rata 86,7 dengan standar deviasi 2,4. Terlihat selisih nilai mean antara pengukuran pertama dan kedua adalah 36,34 (72,15\%) dengan standar deviasi 8,2. Hasil uji statistic didapatkan nilai $\mathrm{P}$ value 0.000 maka dapat disimpulkan terdapat perbedaan yang signifikan antara pengetahuan sebelum dan sesudah intervensi. Hasil yang sama dengan penelitian Nugraha (2014) bahwa rata rata skor pengetahuan gizi total di SD 01 Pondok Cina sebesar 42,35 dan SD sebesar 11,67 dan pada MI Nurul Iman rata-rata sebesar 44,85 dan SD sebesar 10,334. Penelitian Kartini dkk dalam Zulaekah (2012) juga didapatkan ada kecenderungan peningkatan pengetahuan dengan pemberian buku. Hal ini sependapat dengan Pramono dkk (2014) bahwa adanya pengaruh pendidikan gizi terhadap pengetahuan anak sekolah tentang gizi.

\section{KESIMPULAN}

Berdasarkan hasil dan pembahasan dalam penelitian ini, maka 
dapat ditarik kesimpulan sebagai berikut.

Pada penelitian ini didapatkan usia responden adalah 10-12 tahun. Anak dengan usia 10 tahun sejumlah 4 orang $(9,8 \%)$, anak dengan usia 11 tahun sejumlah 25 orang $(61,0 \%)$, dan anak dengan usia 12 tahun sejumlah 12 orang $(29,3 \%)$. Pada penelitian ini didapatkan jenis kelamin responden dikategorikan menjadi 2 yaitu laki-laki dan perempuan. Jenis kelamin laki-laki sejumlah 22 orang $(53,7 \%)$ dan jenis kelamin perempuan sejumlah 19 (46,3\%). Pada penelitian ini pendidikan ayah \& ibu dikategorikan menjadi >SMA/Sederajat dan $<$ SMA/Sederajat, dimana pendidikan ayah sebanyak 35 orang $(85,4 \%)$ dan pendidikan ibu sebanyak 30 orang $(73,2)$. Sedangkan untuk kategori $<$ SMA/Sederajat didapatkan hasil pendidikan ayah sejumlah 6 orang $(14,6 \%)$ dan pendidikan ibu 11 orang (26,8\%). Pengetahuan anak sekolah mengenai pedoman gizi seimbang terlihat bahwa nilai rata-rata pengetahuan anak sebelum dilakukan perlakuan adalah 50,3 dengan standar deviasi 9,1 untuk nilai terendah 35 dan tertinggi sebesar 65 . Sedangkan untuk nilai rata-rata pengetahuan anak sekolah setelah dilakukan perlakuan adalah 85,9 dengan standar deviasi 3,3 dan untuk nilai terendah didapatkan sebesar 80 dan nilai tertinggi didapatkan angka 90 .

Pada penelitian ini perbedaan pengetahuan gizi sebelum perlakuan ratarata nilai pengetahuan sebelum pemberian komik (Pre-Test) adalah 50,37 dengan standar deviasi 9,1 Pada penelitian ini perbedaan pengetahuan gizi setelah intervensi (Post-Test) didapatkan nilai rata-rata $86,7 \%$ dengan standar deviasi 2,4. Terlihat selisih nilai mean antara pengukuran pertama dan kedua adalah $36,34(72,15 \%)$ dengan standar deviasi 8,2 .

\section{DAFTAR PUSTAKA}

Ariawan, I. (1998). Besar Dan Metode Sampel Pada Penelitian Kesehatan. Depok : Jurusan Biostatistika Dan Kependudukan Fakultas Kesehatan Masyarakat Universitas Indonesia. Arimurti, Ditta Irma. (2012). Pengaruh Pemberian Komik Pendidikan Gizi Seimbang Terhadap Pengetahuan Gizi Siswa Kelas V SDN Sukasari 4 Kota Tanggerang Tahun 2012 (Skripsi). Depok : Fakultas Kesehatan Masyarakat. Universitas Indonesia.

Ikada, Delina Citryani. (2010). Tingkat Penerimaan Buku Cerita Bergambar Sebagai Media Pendidikan Gizi dan Pengaruhnya Terhadap Pengetahuan Gizi Anak Sekolah Dasar. Bogor: Fakultas Ekologi Manusia. Institut Pertanian Bogor. Kementerian Kesehatan RI. Peraturan Menteri Kesehatan RI Nomor 75 Tahun 2013 Tentang Angka Kecukupan Gizi Yang 
J.Gipas, November 2018, Volume 2 Nomor2 ISSN 2599-0152 eISSN 2599-2465 http://jos.unsoed.ac.id/index.php/jgps

Dianjurkan Bagi Bangsa Indonesia. Jakarta, 2014.

Mulyani Erry Yudhya, 2014. "Pengetahuan Sikap

Dan Perilaku Gizi Seimbang Anak Sekolah Dasar Di SDN GU 12 Pagi” Jurnal Abdimas 1 No $1,98-104$.

Nugraha, Tri Setya, dkk. 2014. "Pengaruh Komik

Gizi Seimbang Terhadap Peningkatan

Pengetahuan Gizi Seimbang Pada Siswa

Kelas 5 di SDN 01 Pondok Cina dan MI Nurul Iman di Kota Depok Tahun 2014".

Nuryanto, 2014. "Pengaruh Pendidikan Gizi Melalui Komik Gizi Seimbang Terhadap Pengetahuan dan Sikap Pada Siswa SDN Bendungan Di Semarang”. Journal of Nutrition College, Vol. 3, No. 4 Tahun 2014, 925-932.
Nuryanto, dkk. "Pengaruh Pendidikan Gizi Terhadap Pengetahuan dan Sikap Tentang Gizi Anak Sekolah Dasar" Jurnal Gizi Indonesia Vol. 3, No. 1, Desember 2014: 121125.

Saloso, I. (2011). Pengaruh Media Audio (Lagu Anak-Anak) Dan Media Visual (Kartu Bergambar) Terhadap Pengetahuan Gizi (PUGS Dan PHBS) Serta Tingkat Penerimaan Pada Anak Usia Sekolah Dasar Negeri Di Kota Bogor (Skripsi). Bogor : Fakultas Ekologi Manusia. Institut Pertanian Bogor.

Zulaekah Siti, 2012 “Pendidikan Gizi Dengan Menggunakan Media Booklet Terhadap Pengetahuan Gizi” Kesmas 7(2) 127-133. 